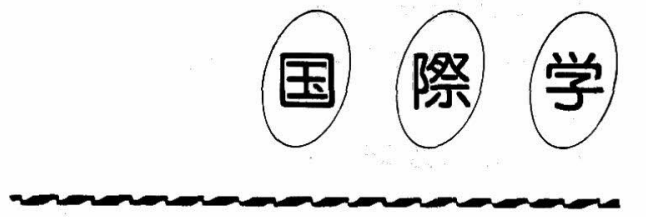

植物分子生物学の動向

第 7 回国際光合成会議

国際光合成会議は，光合成研究における最大規模の発 表の場であり，3 年おきに開催される. 第 7 回国際光合 成会議は, 1986 年 8 月 10 日から 8 月 15 日までの 6 日 間, アメリカ合衆国の東海岸, Rhode Island の州都で ある Providence (Boston の南西約 $70 \mathrm{~km}$ に位置する) に颃いて開催された，会場は，Ivy League に属する名 門校の 1つである Brown University（写真 1) であり， 会議の組織委員長は, J. Biggins（以下敬称略，Brown Univ., アメリカ合衆国) であった. 初日に登録とレセプ ションがあり， 2 日目は, plenary session が 2 会場で行

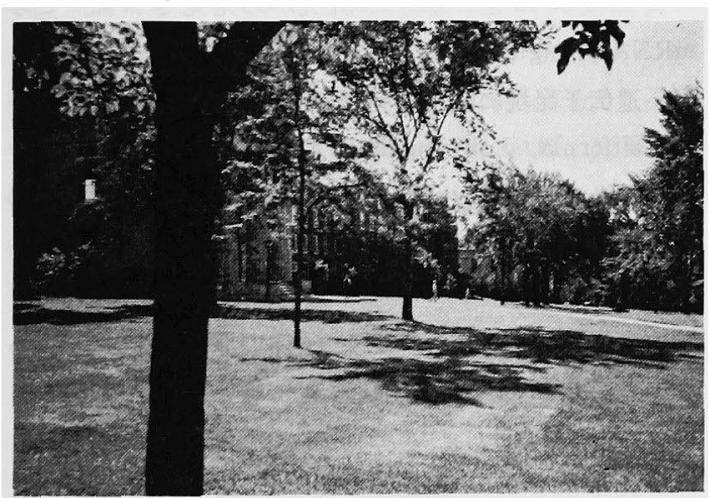

写真 1 会場となった Brown University の構内

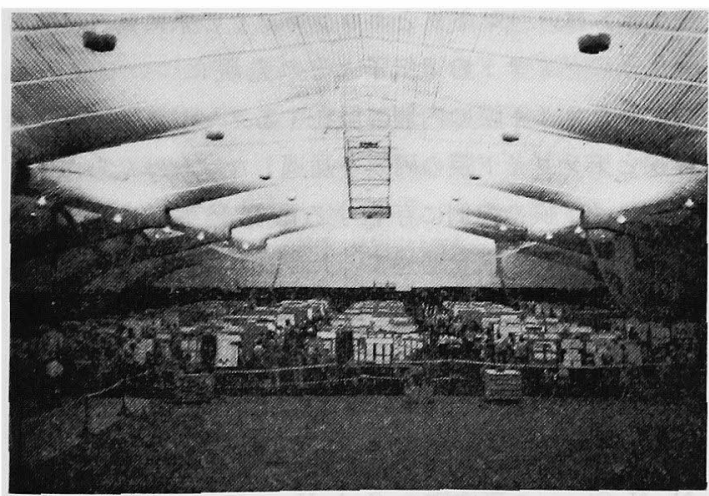

写真 2 Poster session 会場 合話約 700 のポスターか゚ 2 回に分けて展示された

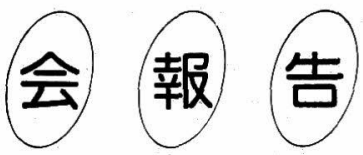

われた. その後，会議の期間を通して午前中に 5 会場で シンポジゥムがあり，午後は poster session (写真 2) および 5 会場に扣いてテーマごとの討論会 (discussion session）があった４日目の午後には，Newport（写真 3, Providence の南約 $40 \mathrm{~km}$ にある帆船基地であり風 光明婮な州立公園) への観光があり, 連日、 コンサート あるいはバーペキューパーティなどの息抜きも用意され ていた. 参加者数の公式発表はないが，参加者は 1,000 名を越光，シンポジウムとポスターをあわせた発表演題 は800に近かった，参加者のうち日本人は, 在米研究者 ああわせて 20 名程度(このらち日本からの会議の組織 委員は基生研の村田紀夫教授）であった. 日本人参加者 には，若い研究者が多かった．日本の蒸し暑い天候に比 べれば快適であったが，会場のいくつかは伝統的建築物 の中にあり，空調と音響には問題があった：音響は一部 の会場（不幸にも筆者の発表会場）において最悪であ り，講演の聞き取りが困難であった．会議の発表内容は 多岐にわたっているが，筆者の興味から分子生物学的研 究について, plenary session とシンポジウム(これらロ 頭発表については abstracts がなく, poster abstracts. のみが配布された）を中心に紹介したい。またすべ ての発表は, proceedings(1) として現在印刷中である. 小稿では，断片的な話題の記述にとどまるので，光合成 遺伝子の研究の全体像については, 総説(2)を参考にして いただけると幸いである。

光合成は，植物においては葉緑体で営まれているが，

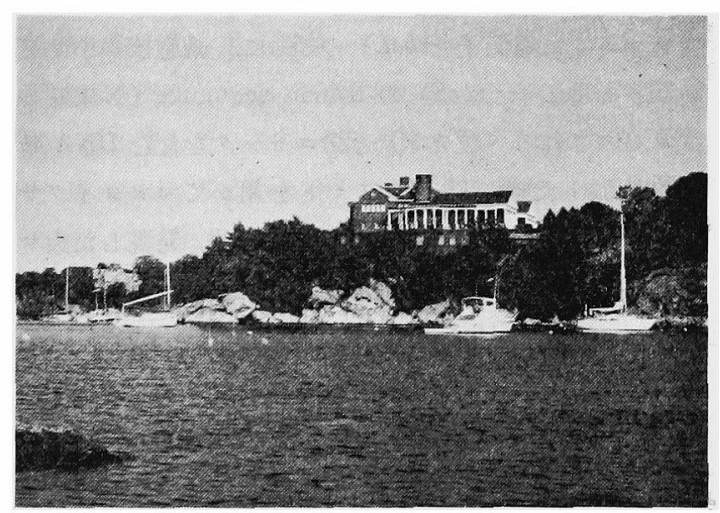

写真 3 帆船の基地として有名な Newport 
一その遺厷情報は葉粶体之細胞核の両方のDNA にコー ドされているまた，藍淂や光合成細菌などの原核生物 は、植物のモデル系として有用でする、したがって，会 議での演題を再編成し，I．葉緑体遺公子，II．細胞核遺 质子, III, 原核生物の順に紹介したい。

\section{I. 葉緑体道伝子}

本会議に初いては発表されなかったにすかかわらず， 初日のレセプションから，日本の2つの研究グループ [杉浦昌弘，篠崎一雄 (名古屋大学) 々小関治男，大山莞 濔 (京都大学)，同じ研究室だと思っている人もいたに 扣いて葉緑体 DNA の全塩基配列が決定されたことは， 大きな話題であったここのニュースは，葉緑体 DNAの シークェンスをしていた海外の当事者達にとっては，当 然のことながらショックのよらであった. M. Edelman (Weizmann Inst. Science, イスラェル) が司会をした discussion session においても，このことは，討論の出 発点となり，葉緑体分子生物学が大きな転機を迎学たこ とを物語った. J. C. Gray (Univ. Cambridge, イキり ス）は、エンドウとコムギの葉緑体 DNA にコードされ ている光合成電子卮達系の膜タンパク質の遗伝子につい て報告した. L. Bogorad 研究室の S. Rodermel (Harvard Univ., アメリカ合臯国) は, トウモロコシの葉緑 体遺伝子の発現が，光に上り正括よび負に制御されて いることを転写産物の解析により明らかにした。再現 性のある葉線体の形質転換系は未だ開発されていない が，葉緑体遺后子の産物を改変する別の試みが紹介され た，葉緑体 DNA の遗伝子の同定では世界的に最も精 力的に研究を行っている R. Herrmann (Univ. Düsseldorf，西ドイッ）は，本来葉緑体 DNA にコードされて いる $\mathrm{CO}_{2}$ 固定の key enzyme である ribulose-1,5ibisphosphate carboxylase/oxygenase (RuBisCO) の大 サブニニット遗伝子 $(r b c L)$ の’に，細胞核の小サブ ユニット遗伀子 $(r b c S)$ の transit sequence ( $N$ 末端の プロセスされるぺプヂととプロモータを含むDNA 断 片を付加した後，Ti プラ.スミドを用いてマッョイグサ (Oenothera）を形質転掺した。 その結果，発現した大サ ブンニットは，葉緑体に輸送され取り込をれた。また， L. Bogorad 5 (Harvard Univ,, アメリカ合鼻国) は,

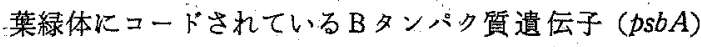
について，同様の試みに成功している，本会議に招いて， 光合成突然变巽体に関する発表は多く，G，W. Schmidt (Univ. Georgia，アメリ力合婪国) は, Chlamydomonas
の突然变異体を用いて事駼を行い，葉箓体 DNA にコ ードされている光化学移思I の遺厷子の発現について議 諭した.

\section{II. 細胞核遗伝子}

葉緑体の遗伝子の全貌が明らか炕なった現在（遗伝子 発現についてはまだ重要な問題が残っている)，細胞核 の光合成遗伝子に研究の比重が夥ってさている. A. R. Cashmore (Rockefeller Univ., $ア \times$ 力合衆国) は土 ンドゥの細胞核にコードされている rbcS と chlorophyll a/b-binding protein 遗伝子(cab) のそれぞれの multigene family について報告した，R.Herrmann (前 述）は,チラコイド膜の主なタンパク質の抗体を調製 し，2gt 11 によライブラリーから遭伝子をスクリーニ ングし，主なチラコイド膜タンパク質の遗伝子をクロー ニングした. W.L. Ogren の共同研究者 A.R. Portis (Univ. Illinois，アメリ力合臬国) は，RuBisCO を活性 化する酵素 RuBisCO activase について報告した. RuBisCO activase は, シロイヌナズナ (Arabidopsis) の突然変異体を作製する研究から発見された。る mRNA はgt 11 とより，クローニングされている。 た，遗伝子発現に関する発表は多く，E.M. Tobin (Univ. California, Los Angeles, アメリカ合傜国)は、アオ ウキクサ (Lemna gibba) を用いて，rbcS 扰よひ $c a b$ 遺伝子の発現の phytochrome，系を介した光制御につい て冁告した. J.E. Mullet (Texas A \& M Univ, アょ リカ合暞国) は、エンドウ葉緑体の形成過程に括ける $c a b$ 遗伝子の発現の制御機棈について述べた。 D.J. Simpson (Carlsberg Lab., デンマーク)は,トウモロコ シの光化学系 II の策光性複合体 LHC II のクロロフィ ルタンパク質について詳細に解析した. 渡边 昭（名古 屋大学）は、エンドウとホウレンソウの系に捣いて酸菜 発生系のペプチドの遺伝子とその発現について発表し た.チラコイド膜の内側に局在するタンパク質は，葉緑 体膜とチラコイド膜の両膜を通過しなければならない。 チラコイド膜の内側に存在する酸素発生系の $33-\mathrm{kDa}$ タンパク賢が，膜を通過するたびに計 2 回プロセスされ "ることを示した:" P. Weisbeek ら (Univ. Utrecht, オラ ンダ) によって、ママンテマ (Silene pratensis) のプラス トシアニンの遺后子を用いた実騟から：プラストシアに ンも2段階にプロセスされることが報告されている。 N.-H. Chua の研究室の S. A. Kay (Rockefeller Univ., アメリカ合采国)は，光に上る葉に特異的な遗伝子の 
発現に関して、エンドウの rbcS 遺伝子に対するcisacting 因子（DNA に直接作用する因子）とDNAの 一次構造について報告した. R. Mache (Univ. Grenoible,フランス)は，ホウレンソウを用いて，葉緑体りボ ゾームを構成するリボゾームタンパク質と rRNA の生 合成について報告した. I. Ohad (Hebrew Univ. Jerusalem,イスラエル)は、トウモロコシの維管束䩗と葉 肉細胞に拈ける葉緑体の分化を免疫化学的手法により研 究した。

\section{III. 原核生物}

藍藻について, D. A. Bryant (Pennsylvania State Univ,, アメリカ合衆国) は, Synechococcus 7002 のフ ィコビリゾームの遺厷子とその発現, およびペプチド の集合について報告した．光合成の律速段階の1つは $\mathrm{CO}_{2}$ 固定反応ですり，光合成效率の増大という観点から $\mathrm{CO}_{2}$ 濃管機構の解明は重要である. A. Kaplan (Hebrew Univ. Jerusalem, イスラェル) は, 監藻 Anacystis nidulans $の$ 高濃度 $\mathrm{CO}_{2}$ 要求性突然变異体を作製 ᄂ た. 往属栄養的に生育の可能な藍藻 Synechocystis 6803 を用いて，同样の試及が T. J. Carison b (E. I. du Pont de Nemours Co., アメリカ合䇐国) によって発表 されている.これらの突然変異体を用いれば，変異相補 性 (complementation) Kより $\mathrm{CO}_{2}$ 濃䌉の遗质子のクロ ーニングが可能である. D. Bradley (Plant Breeding Inst., イギリス) は, A. nidulans の RuBisCO の両サブ ニニット遗公子を大陽菌の中で発現させた，同様に，箻 者らは, 光合成紅色イオウ細菌Chromatium の RuBisCO の両サブユニット遗后子をりローニングし，両遗伝子 を大晹菌の中で tac プロモータにより発現させた大 腸菌の中で両サブュニットが集合して活性の高い酵素分 子が生産されることを発表した。光合成紅色非イオウ細 菌 Rhodopseudomonas capsulata は，従属栄㙋的に生 青が可能であり，多数の光合成突然変貲体が作製されて いる，R. capsulata は，グラム陰性菌であり，R’プラス ミドによる形質転換が可能である．したがって，突然変 異体の変異相補性により光合成の遗伝子がクローニング されている. G.Drews (Albert-Iudwigs-Univ., 西ドイ \%) は， R. capsulata K执ける光合成色素-タッパク質 複合体の形成について報告した. B. L. Marrs（Exxon Res. Engineering Co., アメリカ合衆国) は，R.capsuLata の分子遣云子学に括いて，先駆者としての栄績が大 きいが，今回は，反応中心の遗伝情報発現について報告
した. D, C. Youvan (Cold Spring Harbor Lab., アメリ カ合自国) は, R. capsulata の光合成反応中心いいて, site-specific mutagenesis を行った。 L就よびMサブニ ニットは、トリアジン除草剤子結合する葉緑体のBタン ヘク筫と相同性が高くこの薬剂と結合する. site-specific mutagenesis により，薬剂耐性の活性中心が作製さ れだ、た，X線結晶解析を行い，タンパク質の一次構 造之高次檴造の関係を考察した. F. Daldal (Cold Spring Harbor Lab., アメリカ合衆国) は, R. capsulata cyt $b / c_{1}$ 複合体の遗伝子を突然変異体の変異相補性に よりクローニングし，DNA 塩基配列を決定した.これ らの奏験をもとにして，cyt $b / c_{1}$ 複合体の榡造と機能に ついて議論した。

この会議に氺ける日本人の活躍には目ざるしいものが めった、日本人の参加者は少なかったが、すべての方及

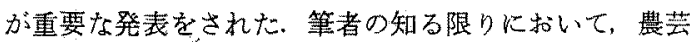
化学分野の日本人参加者として，横田明穗ら（大阪府立 大学) は，Chlamydomonas reinhardtii に和ける光合成 $\mathrm{CO}_{2}$ 固定とグリコール酸合成の関保について発表した。

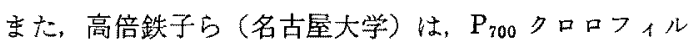
a タンパク質複合体，プラストシアニン， cyt $b_{6} / f$ 複合 体の蓄積と分解について発表した，また，中華人民共和 国からは約 20 名の参加があり，とくに人目を引いた。 新しい中国の側面を誢がた。

筆者は，この機会を利用して，植物分子生物学见必け る2大旦頭ともいえる L. Bogorad (Harvard Univ.) と N.-H. Chua (Rockefeller Univ.) の研究室を訪れた。 両研究室の研究内容の一部はすで紹介したと必りであ る.筆者は, 1983 年から 1984 年まで Bogorad の研 究室で研究する機会を得たが，その後，post-doctoral fellows の大半は入れ替わっている. 依然総勢約 30 名の 活気を保っていた，現在，トウモロコシ葉緑体DNAの 研究は主流ではなく，研究対象は，藍藻から高等植物ま で多種に及んでいる，一方，Chua は，Rockefeller 財时 と Monsanto Co. 加莫大な研究費を得て，まさに破竹 の勢いである. post-doctoral fellowsを 25 名以上抱点， 総勢は 40 名にも及ぶ. 研究材料は高等植物を主として 拈り，研究成果の1つはイネに集約していくようであ る.

以上アメリカ合乗国東海岸で得た植物分子生物学の現 状に関する知見を紹介した，植物，藻類，および光合成 細菌の形質転換系が開発されるに及んで，光合成の研究 
に reverse genetics（遗伝子を改変し発現させる方法 論）が盛んに活用されている。またこれらの方法論と あわせて, 光合成笑然変異体は大変有用である. 遗伝子 の構造解析が出発点となり, 研究はさらに発展すると思 われる. 研究の到達点の 1 つが, 光合成効察の增大であ ることは明白である.この研究目的とするところは，農 芸化学の研究姿勢々一致すると思われる. 農芸化学の研 究分野において，光合成の研究にさらに一層のご理解を いただけると大変幸いである。

最後に，筆者は(財)農芸化学研究䍃励会からの渡航費 のご援助を頂いた，同会に感謝したい：なた、シンポジ
ウムでの発表の機会を与えて下さった名古屋大学 赤沢 堯 教授に深甚なる謝意を表したい，あわせてここに 揭載している写真を撮影提供して下さった渡辺昭博士お よび横田明㯖博士に感謝する。また，小稿に対する意見 を聞かせてくれた小林京子(名古屋大学) に感謝する。

（名古屋大学アイソトープ総合センター 小林裕租）

(1) "Progress in Photosynthesis Research" ed. by J. Biggins, Martinus Nijhoff Publishers, Dordrecht, 印刷中

（2）小林裕和：現代化学增刊 5 「植物ハイオテク， 口ジー」山田, 岡田編, 東京化学同人, 1986, pp. 173-189.

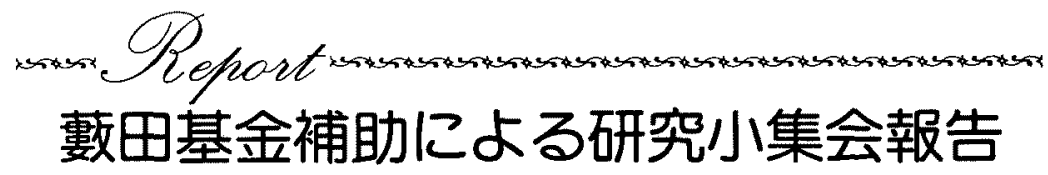

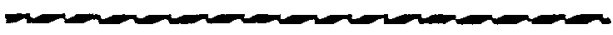

「コマの科学」一载培植物学と食糧科学

名大名誉教授 並木満夫

去る昭和 61 年 9 月 26 日, 27 日の両日に, ゴマの科 学について世界でも初めての研究会が，三河湾を一望に 収爰根山上の三河ハイッで日本農芸化学会の研究小 集会の補助をらけて開催された. こ゚は多くの日常語に あるように古くから医薬効果をるつ重要な油踏食品とし て広く世界で賞用されて来た食品である。 その植物起源 は遠くアフリカスーダン地方とされ紀元前 3000 年以上 前から栽培されていた最る古い油糧植物である. 貴重な 油脂資源として古くがせ界に伝播し、メンポタミア， インドを経て中国に渡り、日本には仏教とともに約 1500 年前に渡来し，かつては日本中に栽培されていた。 このよらなコマの载培植物学に护る世界的な研究が富 山大学の小林貞作教授によってなされて来た。

一方，著者らは食と健康の原点に立って食品の健全性 について新しい倠点と総合的な評価をむって研究を進め ており，その一つとして抗酸化性を指標として各種食品 の機能性を解析して来たが，その興味ある材料としてコ マを取り上げ 10 年来その化学的研究を続けて来た。 I マは古くから医食同源的な賞用をされて来たが，その科
学的根捼は注とんど知られていなかった.ゴマ油の高い 酸化安定性についてはその特有のフニノール化合物セサ モールによるとされてきたが，著者らの研究によりそれ は実際には微量で効果は少なく，新しく sesaminol, sesamolinol と名付けた抗酸化物質の存在が明らかにされ た.このような背景から私は小林点作教授の協力を之て ゴマの研究会を企画し，幸い研究小集会の補助をえて開 催することになった.

コマに関して本格的に研究している人はわが国です限 られているが，今回別記のよ5に载培植物学から食品化 学、工学末で広い分野の研究者を集めこれまでの成果を 発表討諭し，今後の発展を考皇るため泊り込及で勉强す る小集会を計画した，ところが開催通知が遅れたのにか かからず参加申込が殺到し，大学研究所は元より多くの 民間企業からの方を合せて 110 名以上になって対応に 追われる始末であった。

研究会は26日午後から，企画者の「開けゴマの科 学」の挨猡に始りまず松枝弘一（竹本油脂）は「ゴマの 油脂科学」について，種子の油脂含量は 50\%以上に及 び，主にりノール酸，オレイン酸よりなる良質なもので あること，日本，中国などでは焙前して搾油した焙煎油 が多いが，欧米等で用いられる生絞りのサラダ油も秮れ たるのであることが紹介された。ついで名大食品製造化 学第工研究室に心いて。ここ十年近く精力的に取組んで 